\title{
The Chilopoda and Diplopoda of the southern Carnarvon Basin, Western Australia
}

\author{
Mark S. Harvey ${ }^{1}$, Alison Sampey ${ }^{1,2}$, Paul L.J. West ${ }^{1,3}$ and Julianne M. Waldock \\ ${ }^{1}$ Department of Terrestrial Invertebrates, Western Australian Museum, \\ Francis Street, Perth, Western Australia 6000, Australia \\ ${ }^{2}$ Present address: Lot 1984 Weller Rd, Hovea, Western Australia 6007, Australia \\ ${ }^{3}$ Present address: Halpern Glick \& Maunsell Pty Ltd, John Tonkin Centre, \\ 629 Newcastle St, Leederville, Western Australia 6007, Australia
}

\begin{abstract}
At least 15 species of centipedes and 11 species of millipedes were recorded from the southern Carnarvon basin. Centipede diversity is dominated by scolopendrids with 13 species, but most species are relatively widespread both within the survey area and in other regions of Western Australia. Centipede communities were found to be strongly correlated with rainfall and soil texture variables. Millipede diversity is dominated by members of the paradoxosomatid genus Antichiropus which is represented by seven undescribed species, five of which are restricted to individual survey areas. The other two species are found at two and three survey areas, respectively. These distribution patterns are seen elsewhere in Western Australia with Antichiropus which contains many highly localised species.
\end{abstract}

\section{INTRODUCTION}

The myriapods are an assemblage of the four classes Chilopoda (centipedes), Diplopoda (millipedes), Symphyla (symphylans) and Pauropoda (pauropods), all of which are known to occur in Australia (Harvey and Yen, 1989). Symphylans and pauropods are small and generally restricted to wetter biotopes, whereas centipedes and millipedes are found in many types of terrestrial environments. As with so many other invertebrate groups, data on the myriapod fauna of the semi-arid and arid zones of Australia are fragmentary, mainly being derived from specimens collected opportunistically and for taxonomic revisions.

This paper attempts to examine patterns in the composition of the myriapod communities of the southern Carnarvon Basin, Western Australia through an intensive pitfall trapping program at 63 localities (Figure 1) positioned in a stratified random array to represent the geographical extent and range of major geomorphological units of the study area. Species occurrences were analysed for correlations with numerous physical attributes measured for each site.

Our knowledge of the myriapod fauna of the Carnarvon Basin is somewhat fragmentary, with the scolopendrid centipede fauna being the best studied element (e.g. Kraepelin, 1908; Koch, 1982; Koch, 1983d; Koch, 1983a; Koch, 1983c) (Tables 1, 2). Other groups of centipedes are poorly known and one group, the Geophilida, could not be identified to species level due to our insufficient knowledge of species-level characters in this diverse and complex group. The millipedes are also poorly known with only a single species having been previously reported for the area (Attems, 1911). However, in contrast to the geophilids, we were able to satisfactorily separate species using the peculiar morphology of the male gonopods.

\section{MATERIAL AND METHODS}

\section{Study Area}

The survey area of the southern Carnarvon Basin covers some $75000 \mathrm{~km}^{2}$ in the central region of Australia's west coast. It is centred on Shark Bay and extends from the Murchison River in the south to the Minilya River in the north, and eastwards to beyond Gasgoyne Junction (Figure 1). The physical environment is discussed by Wyrwoll, Stoneman, Elliott and Sandercock (2000) and Wyrwoll, Courtney and Sandercock (2000). The climate is semi-arid with temperate weather systems in the southern half of the survey area, and tropical and temperate systems in the northern half.

The survey area covers the northern half of the Irwin District of the Southwestern Province, and the southern half of the Carnarvon District of the Eremean Province (Beard, 1980). The vegetational characteristics are documented by Keighery $e t$ al. (2000). 


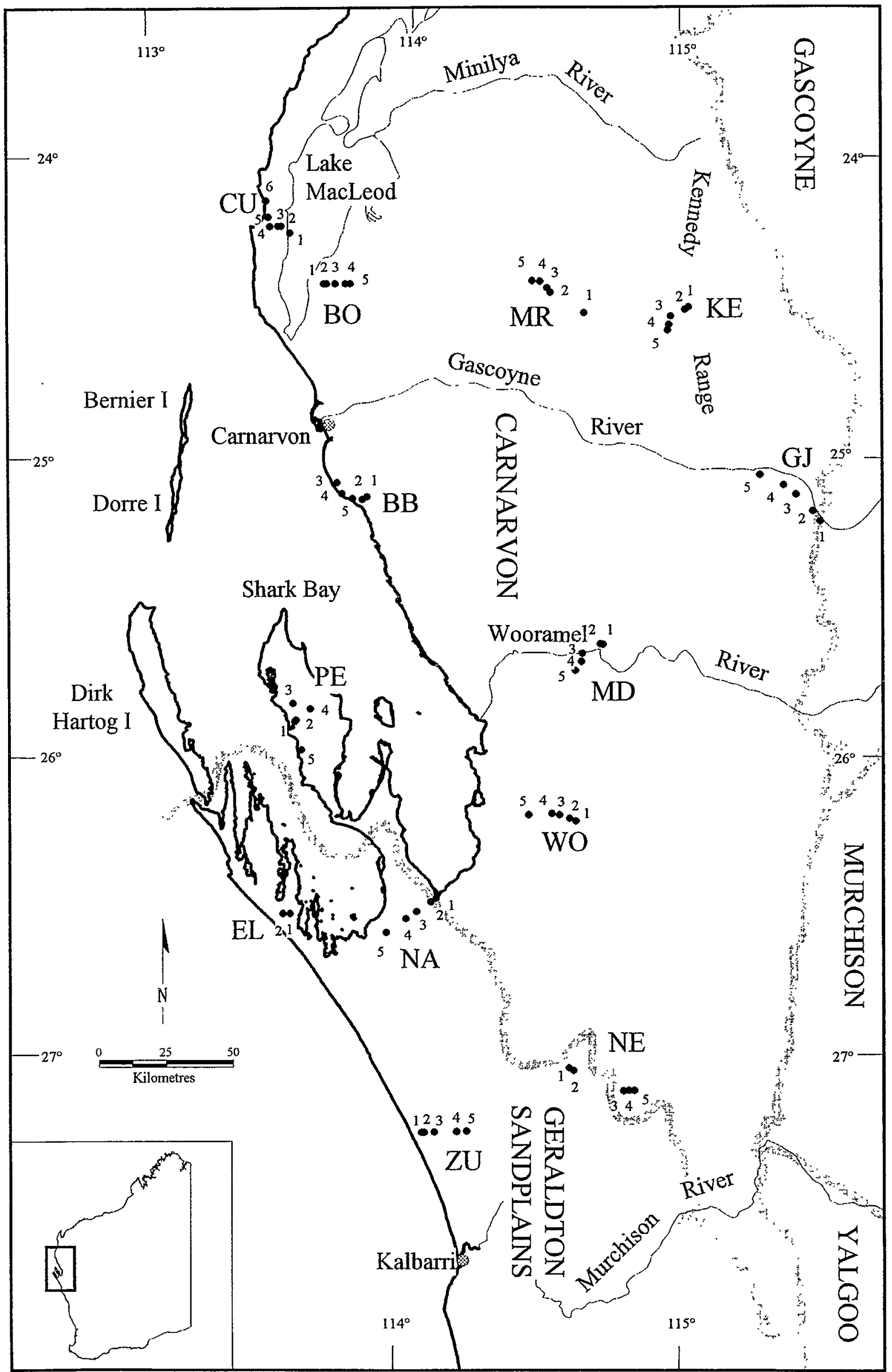

Figure 1 Map of the study site showing sites utilised in the study. 
Table 1 Centipedes previously recorded from the southern Carnarvon basin.

\begin{tabular}{|c|c|c|c|c|}
\hline Species & Family & General distribution & $\begin{array}{l}\text { Distribution within southern } \\
\text { Carnarvon basin }\end{array}$ & Authority \\
\hline $\begin{array}{l}\text { GEOPHILIDA } \\
\text { Lamnonyx tahitiensis Wood }\end{array}$ & Geophilidae & Widespread in the Australasian region. & Tamala & Attems (1911) \\
\hline Tuoba sydneyensis (Pocock) & Geophilidae & $\begin{array}{l}\text { Widespread in coastal regions of } \\
\text { Australia, New Guinea, Solomon Islands. }\end{array}$ & Denham; Eagle Bluff & Attems (1911), Jones (1998) \\
\hline $\begin{array}{l}\text { SCOLOPENDRIDA } \\
\text { Cormocephalus aurantiipes (Newport) }\end{array}$ & Scolopendridae & Widespread across mainland Australia. & Carnarvon; Dorre Island & Koch $(1983 c)$ \\
\hline Cormocephalus turneri Pocock & Scolopendridae & $\begin{array}{l}\text { Widespread across the drier portions of } \\
\text { southern Australia. }\end{array}$ & Dirk Hartog Island & Kraepelin (1908), Koch (1983c) \\
\hline Ethmostigmus pachysoma L.E. Koch & Scolopendridae & Known only from three WA localities & Mardathuna Station; Tamala & Koch (1983d) \\
\hline Ethmostigmus rubripes (Brandt) & Scolopendridae & $\begin{array}{l}\text { Widespread across mainland Australia, } \\
\text { as well as parts of Indonesia, New } \\
\text { Guinea, Solomon Islands and China. }\end{array}$ & $\begin{array}{l}\text { Baba Head; Denham; Dirk Hartog } \\
\text { Island; Dorre Island; Edel Land }\end{array}$ & Kraepelin (1908), Koch (1983d) \\
\hline Scolopendra laeta Haase & Scolopendridae & Widespread across mainland Australia. & $\begin{array}{l}\text { Denham; Dorre Island; Gee Gie } \\
\text { Outcamp; } 10 \mathrm{~km} \text { ESE of Meedo } \\
\text { Homestead; Tamala }\end{array}$ & Kraepelin (1908), Koch (1982) \\
\hline Scolopendra morsitans Linnaeus & Scolopendridae & $\begin{array}{l}\text { Cosmopolitan and widespread } \\
\text { within Australia. }\end{array}$ & $\begin{array}{l}\text { Baba Head; Boologooro Station; } \\
\text { Calligiddy; Carnarvon; Coburn } \\
\text { Station near Hamelin Pool; } \\
\text { Denham; Dirk Hartog Island; } \\
\text { Gee Gie Outcamp; Shark Bay area; } \\
\text { Tamala; } 8 \text { km NE. of Tamala } \\
\text { Homestead; Useless Loop }\end{array}$ & Kraepelin (1908), Koch (1983a) \\
\hline
\end{tabular}


Table 2 Millipedes previously recorded from the southern Carnarvon basin.

\begin{tabular}{lllll}
\hline Species & Family & General distribution & $\begin{array}{l}\text { Distribution within } \\
\text { southern Carnarvon } \\
\text { basin }\end{array}$ & Authority \\
\hline $\begin{array}{l}\text { POLYDESMIDA } \\
\text { Antichiropus monocanthus } \\
\text { Attems }\end{array}$ & Paradoxosomatidae & $\begin{array}{l}\text { Described from three WA } \\
\text { localities, including two in } \\
\text { the southern Carnarvon Basin; } \\
\text { subsequently not recorded in } \\
\text { the literature. }\end{array}$ & $\begin{array}{l}\text { Dirk Hartog } \\
\text { Island; Tasmania }\end{array}$ & Attems (1911) \\
\hline
\end{tabular}

\section{Field Sampling}

The survey was based upon 63 quadrats in 13 groups of two to six (but usually five). Each group is termed a 'survey area'. The quadrats were positioned to cover the geographical extent of the study area, represent the array of stratigraphic units present and provide some pseudoreplication of its main substrate types.

Sampling was conducted with the aid of two different types of pitfall traps. Specimens were also hand collected during the field program, but to date we lack the resources to sort and label this material. All specimens are lodged in the Western Australian Museum, Perth.

Live specimens were removed from vertebrate pitfall traps (seeMcKenzie et al., 2000) during each five-day trapping program (September-October 1994, May-June 1995) and preserved in 75\% ethyl alcohol.

Wet pitfall traps consisted of 25 litre buckets $(300$ $x 400 \mathrm{~mm}$ ) dug into the ground, with the top flush with the soil surface. Each was fitted with a lid into which five $10 \mathrm{~cm}$ diameter holes were cut. A piece of chicken wire (c. $1 \mathrm{~cm}$ mesh) was suspended below the lid to allow any vertebrate which ventured into the trap to escape. This may have enabled larger invertebrates such as beetles and spiders to escape although a $2.5 \mathrm{~cm}$ gap was left between the wire and the wall of the bucket. Each trap was equipped with approximately 3.5 litres of preserving fluid ( 3 l ethylene glycol, $40 \mathrm{ml}$ formalin, $350 \mathrm{ml}$ water). The traps were opened in August 1994, and the contents were cleared in SeptemberOctober 1994, January 1995, May-June 1995 and August 1995, when they were removed. Samples were returned to the laboratory, washed in water and stored in $75 \%$ ethyl alcohol until being sorted. Target organisms were removed, labelled and placed in separate vials or jars.

Five wet pitfall traps were placed in each of the 63 quadrats, the total number of traps utilised being 315 . Over the 12-month trapping period, we had the equivalent of some 115,000 trap nights. The 12month trapping period allowed for the full sampling of all seasons, and reduced the suspected bias which may occur in restricted sampling periods.

\section{Data Analysis}

The data matrix (Table 3) comprised the presence and absence of species on each quadrat, rather than their relative abundance. It was analysed using the computer package PATN (Belbin, 1993) to procure species composition patterns. The association measure 'Two-step' was used to determine the quantitative relationship between each pair of species, and the Czekanowksi measure was used to compare the quadrats according to their species similarities. The dendrograms derived from these association matrices were derived using a modified 'unweighted pair group arithmetic averaging' (UPGMA) hierarchical clustering strategy (Sneath and Sokal, 1973).

The biological patterns revealed by these analyses were investigated in terms of a set of attributes related to the physical environments of the quadrats presented by Wyrwoll, Stoneman, Elliott and Sandercock (2000) utilising the GSTA module in PATN, and assessed statistically with KruskalWallis K-sample tests.

\section{RESULTS}

Several thousand myriapod specimens in more than 1080 vials were sorted and identified during the current survey, representing two classes, centipedes and millipedes. Of the centipedes, three of the five known orders were recorded in the survey area, whereas only four of the nine known Australian orders of millipedes were recorded.

\section{Chilopoda}

A total of 15 species were recorded from the 63 quadrats (Table 3), ranging from two species/site at two sites (MD1 and PE1) to 11 species/site at two sites (KE2, KE3).

\section{Geophilida}

Members of the order Geophilida are slender, long-bodied centipedes which we recorded at 31 sites. Any resolution of biogeographical patterns within this taxon were concealed because we were unable to identify our specimens past ordinal level. 
Table 3 Centipedes and millipedes collected during the present survey.

\begin{tabular}{|c|c|c|c|c|c|c|c|c|c|c|c|c|c|c|c|}
\hline & & & \begin{tabular}{|llllll}
$B B$ & & & & \\
1 & 2 & 3 & 4 & 5
\end{tabular} & $\begin{array}{llllll}B 0 & & & \\
1 & 2 & 3 & 4 & 5\end{array}$ & \begin{tabular}{|llllllll}
$\mathrm{CU}$ & & & \\
1 & 2 & 3 & 4 & 5 & 6
\end{tabular} & \begin{tabular}{|l|}
$\mathrm{EL}$ \\
12
\end{tabular} & $\begin{array}{lllll}\text { GJ } & & \\
12 & 3 & 4 & 5 \\
\end{array}$ & \begin{tabular}{|llllll}
$\mathrm{KE}$ & & & \\
1 & 2 & 3 & 4 & 5 \\
\end{tabular} & $\begin{array}{llll}M D & & & \\
1 & 2 & 3 & 4\end{array}$ & $\mid \begin{array}{lllll}\text { MR } & & & \\
1 & 2 & 3 & 4 & 5 \\
\end{array}$ & $\begin{array}{|lllll|}\text { NA } & & & \\
1 & 2 & 3 & 4 & 5 \\
\end{array}$ & \begin{tabular}{|lllll|l|l|}
$\mathrm{NE}$ & & & \\
& 2 & 3 & 4 & 5 \\
\end{tabular} & \begin{tabular}{|lllllll}
$\mathrm{PE}$ & & & \\
1 & 2 & 3 & 4 & 5 \\
\end{tabular} & \begin{tabular}{|lllll}
$W 0$ & & & \\
1 & 2 & 3 & 4 & 5 \\
\end{tabular} & $\begin{array}{lllllll}\mathrm{ZU} & & & \\
1 & 2 & 3 & 4 & 5 \\
\end{array}$ \\
\hline CHILOPODA & & & & & & $\mathrm{Ix}$ & & & $X$ & & $x \times \mid$ & & $x$ & & $x \times x x$ \\
\hline $\begin{array}{l}\text { Geophilida } \\
\text { Scolopendrida }\end{array}$ & Scolopendridae & $\begin{array}{l}\text { spp. } \\
\text { Asanada sp. }\end{array}$ & $x \times \times x$ & $\left|\begin{array}{llll}x & x & x & x\end{array}\right|$ & $x \times$ & $j^{x}$ & $\begin{array}{l}x \\
x\end{array}$ & $\left|\begin{array}{lll}x & x & x\end{array}\right|$ & $\mathrm{x}$ & $\mathrm{x} x$ & & & & & \\
\hline Scolopendrida & Scolopendridae & $\begin{array}{l}\text { Arthrorhabdus mjobergi } \\
\text { Arthrorhabdus paucispinus }\end{array}$ & $\begin{array}{llll}x & x & & \end{array}$ & $\mathrm{X}$ & $x$ & & $\mathrm{x}$ & 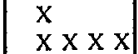 & $x x$ & $x \times x \times$ & & $\mathrm{x} \times \mathrm{x}$ & & $\mathrm{x} \times \mathrm{x} \times \mathrm{x} \times$ & \\
\hline $\begin{array}{l}\text { Scolopendrida } \\
\text { Scoiopendrida }\end{array}$ & $\begin{array}{l}\text { Scolopendridae } \\
\text { Scolopendridae }\end{array}$ & Arthrorhabdus sp. & 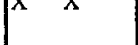 & $\begin{array}{l}x \\
x\end{array}$ & $x$ & & & $|\times x \times x|$ & & & & & & & \\
\hline Scolopendrida & Scolopendridae & Cormocephalus aurantipes & $\mathrm{x}$ & & $\mathrm{x} \times \mathrm{x} \times \mathrm{x}$ & $\mathrm{x} x$ & & $x \times x$ & $\mathrm{x}$ & & $|x \times x \times x|$ & 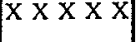 & $\times \times \times x$ & $\mathrm{xx}$ & $|x \times x \times x|$ \\
\hline Scolopendrida & Scolopendridac & Cormocephalus strigosus & $\mathrm{Y} Y \mathrm{Y}_{\mathrm{Y}} \mathrm{Y}$ & $\mid \begin{array}{rl}x & x \\
y & x\end{array}$ & $\mathrm{x} x \mathrm{x}$ & & $|x \times x \times x|$ & 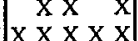 & $x \times x x$ & $|x \times x \times x|$ & $|x \times x \times x|$ & $|x \times \times x \times|$ & $x \times x \times$ & $\mathrm{x} \times \mathrm{x} \times \mathrm{x}$ & $x \times x \times$ \\
\hline $\begin{array}{l}\text { Scolopendrida } \\
\text { Scolopendrida }\end{array}$ & $\begin{array}{l}\text { Scolopendridae } \\
\text { Scolopendridae }\end{array}$ & $\begin{array}{l}\text { Cormocephulus turneri } \\
\text { Ethmostigmus curtipes }\end{array}$ & 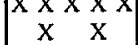 & 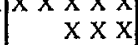 & $x \times x \times x$ & $\mathrm{x} x$ & $\sin x$ & $\mid \hat{x} \times \hat{x}$ & & $x \times x$ & $|x \times x|$ & {$\left[\begin{array}{ll}x & x\end{array}\right]$} & $\mathrm{x} x \quad \mathrm{x}$ & & \\
\hline Scalopendrida & Scolopendridae & Ethmostigmus pachysoma & & & & & $x \times x$ & $x x$ & & $\left|\begin{array}{ll}x & x\end{array}\right|$ & & & & & \\
\hline $\begin{array}{l}\text { Scolopendrida } \\
\text { Scolopendrida }\end{array}$ & Scolopendridae & Ethmesstigmus parkeri & & $|x \times x \times x|$ & $\mid x \times x \times x \times$ & $|x x|+2+2$ & $x \times x \times$ & $x \quad x$ & $6 x \times$ & 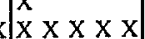 & $\mathrm{x} \times \mathrm{x}$ & $|x \times \times \times x|$ & $|x \times x \times x|$ & $x \times x$ & $|x \times x \times x|$ \\
\hline $\begin{array}{l}\text { Scolopendrida } \\
\text { Scolopendrida }\end{array}$ & $\begin{array}{l}\text { Scolopendridae } \\
\text { Scolopendridae }\end{array}$ & $\begin{array}{l}\text { Ethmostigmus rubripes } \\
\text { Scolopendra laeta }\end{array}$ & 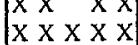 & 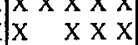 & 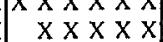 & $\mid \begin{array}{ll}x \\
x \times x\end{array}$ & & $\hat{x} \times \hat{x}$ & $x \times x$ & $|x \times x \times x|$ & $|x \times x \times x|$ & $|x \times x \times x|$ & $\mid x \times x \times$ & $x \times x \quad x$ & $x \times x \times x$ \\
\hline Scolopendrida & Scolopendridae & Scolopendra morsitans & $|x \times x \times x|$ & $|x \times x \times x|$ & $|x \times x \times x|$ & & $|x \times x \times x|$ & $|x \times x \times x|$ & $x \times x \times x$ & $|x \times \times \times x|$ & $|x \times x \times x|$ & $x \times x \times x$ & $x \times x \times$ & $\times \times \times \times x$ & $|x \times x \times x|$ \\
\hline Scutigerida & Scutigeridae & Allothereua sp. & $\mathrm{x} \times \mathrm{x} \times$ & $\times x$ & $\mathrm{x} \quad \mathrm{x} \times \mathrm{x} \times$ & $\mathrm{x} x$ & $|x \quad x \times x|$ & $|x \times x \times x|$ & $\mathrm{x} x$ & $|\times \times \times x|$ & $\mathrm{x} \times \mathrm{X}$ & & $\left|\begin{array}{lll}x & x & x\end{array}\right|$ & $\mathrm{X} \times \mathrm{X} \times \mathrm{X}$ & $x \times x$ \\
\hline $\begin{array}{l}\text { DIPLOPODA } \\
\text { Polydesmida }\end{array}$ & Paradoxosomatidae & Antichiropus sp. 1 & & & & & & & & & & & & & $x \times x \times x \mid$ \\
\hline Polydesmida & Paradoxosomatidae & Antichiropus sp. 2 & & & & & & & & & & & & & \\
\hline Polydesmida & Paradoxosomatidae & Antichiropus sp. 3 & & & & $\mathrm{x}$ & & & & & & & & & \\
\hline Polydesmida & Paradoxosomatidae & Antichiropus sp. 4 & & & & & & & & & & & $x$ & & \\
\hline Polydesmida & Paradoxosomatidae & Antichiropus sp. 5 & & & & & & & & & $x$ & & & & $\boldsymbol{\Lambda}$ \\
\hline Polydesmida & Paradoxosomatidae & Antichiropus sp. 6 & & & & & & & & & & $\mathrm{y} y$ & & & \\
\hline $\begin{array}{l}\text { Polydesinida } \\
\text { Polyxenida }\end{array}$ & $\begin{array}{l}\text { Paradoxosomatidae } \\
\text { Polyxenidae }\end{array}$ & $\begin{array}{l}\text { Antichiropus sp. } 7 \\
\text { Genus 1, sp. } 1\end{array}$ & & $x x$ & $x$ & $\mathrm{x}$ & & & & & & $x \times$ & & & \\
\hline $\begin{array}{l}\text { Polyxenida } \\
\text { Polyxenida }\end{array}$ & $\begin{array}{l}\text { Polyxenidae } \\
\text { Synxenidae }\end{array}$ & $\begin{array}{l}\text { Genus 1, sp. } 1 \\
\text { Genus 1, sp. } 1\end{array}$ & & $\mathrm{xx}$ & & & & & & & & $x y$ & & $\mathrm{x}$ & \\
\hline Polyzoniida & Siphonotidae & Genus 1, sp. 1 & & & $\mathrm{x}$ & & & & & $x$ & $\mathrm{x}$ & $X X$ & & & $\mid \begin{array}{rl}\lambda \\
x \times x & x\end{array}$ \\
\hline
\end{tabular}




\section{Scolopendrida}

Thirteen species of scolopendrid centipedes, representing five genera, were collected during the survey.

Asanada sp. was collected at seven sites (Table 3), but the relationship between this population and those recorded from northern Queensland (Koch, 1983b) and Woodstock Station in the Pilbara (Harvey and Waldock, 1991) remains to be determined. It now seems that Asanada is widespread across northern Western Australia.

Only two Australian species of Arthrorhabdus were identified in a recent revision of the genus (Koch, 1984), and both were newly recorded from the study area (Table 3). Arthrorhabdus mjobergi was collected once at KE2, while $A$. paucispinus was collected at 23 sites across much of the study area. An unidentified species, A. sp., was taken at BO1.

Kraepelin (1908) and Koch (1983c) recorded two species of Cormocephalus from the study area, $C$. aurantiipes and $C$. turneri (Table 1). Both of these species were recollected during the survey, $C$. aurantiipes from 34 sites and C. turneri from all but seven sites (Table 3). Cormocephalus strigosus is newly recorded from the area, although Koch (1983c) recorded the species from sites to the north (Barrow Island) and south (e.g. Mullewa, Northampton) of the Carnarvon basin.

Two species of Ethmostigmus have been previously recorded from the study area, E. rubripes and E. pachysoma (Kraepelin, 1908; Koch, 1983d) (Table 1). We recorded these two species, as well as E. curtipes and E. parkeri. Ethmostigmus rubripes is widespread over much of mainland Australia, including several sites in the Shark Bay area (Kraepelin, 1908; Koch, 1983d) (Table 1). We recorded it from all but eight sites in the study area (Table 3). Ethmostigmus curtipes was taken from most survey areas, with the exception of Gascoyne Junction, Meedo, Woodleigh and Zuytdorp (Table 3). It was previously known from inland areas of Western Australia (Koch, 1983d). Ethmostigmus pachysoma was previously known from only three localities, all situated in Western Australia (Koch,
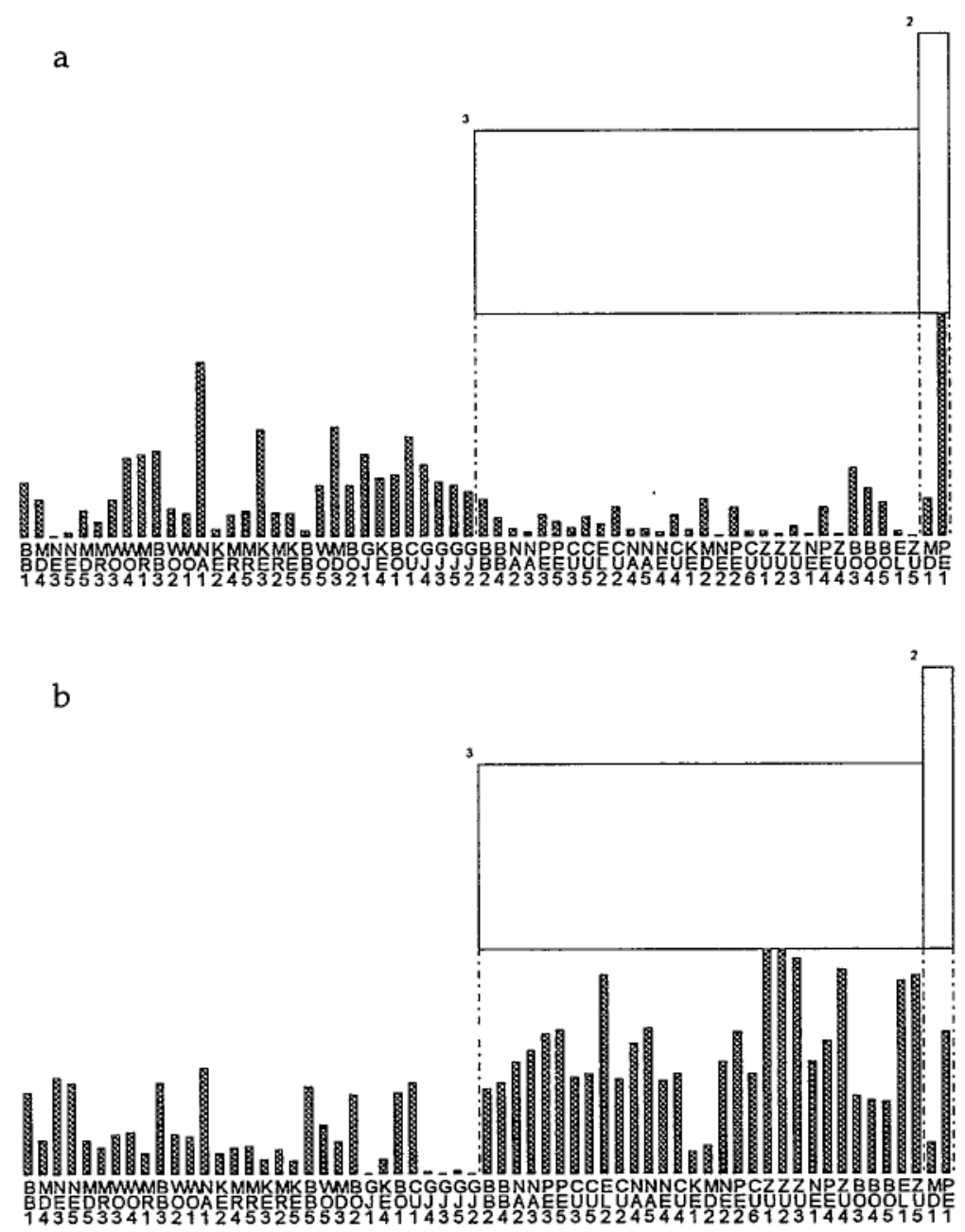

Figure 2 Attribute values for (a) precipitation in the wettest quarter (PwetQ), and (b) soil potassium $\left(\mathrm{K} \mathrm{HCO}_{3}\right)$ superimposed as histograms on the dendrogram structure derived from the classification of the 63 quadrats in terms of species belonging to the assemblage. Quadrat codes are printed vertically. Note that PwetQ and $\mathrm{K} \mathrm{HCO}_{3}$ were inversely inter-correlated in the study area. 
Table 4 Centipede data matrix, reordered according to species co-occurrences.

\begin{tabular}{|c|c|c|c|}
\hline Species & Sites & & \\
\hline & BMNNMMWWMBWWNKMMKMKBWMBGKBCGGGG & |BBNNPPCCECNNNCKMNPCZZZNPZBBBEZ & MP \\
\hline & BDEEDROORBOOAERREREBODOJEOUJJJJ & |BBAAEEUULUAAEUEDEEUUUUEEUOOOLU| & $D E$ \\
\hline & 1435533413211245325553214114352 & 242335352245441222612314434515 & 11 \\
\hline Asanada sp. & * $\quad * * * * \quad *$ & & \\
\hline Arthrorhabdus paucispinus & $* * * * * * * * \quad * * * \quad * * * * * * \quad * \quad * * *$ & ** & \\
\hline Ethmostigmus pachysoma & $* * * * * *$ & & \\
\hline Cormocephalus strigosus & * $* *$ & ** & | \\
\hline Cormocephalus aurantiipes & $* * \quad * \quad * * * * * \quad *$ & | $\quad * * * * * * * * * * * * * * * * * * * * * * * \quad * * \mid$ & \\
\hline Ethmostigmus curtipes & $* * * * *$ & $\mid * * * * * * * * * * * * * * * * * \quad * \quad$, & \\
\hline Cormocephalus turneri & 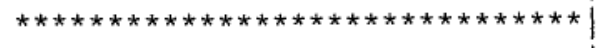 & 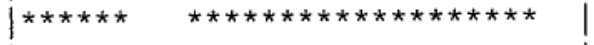 & \\
\hline Scolopendra morsitans & 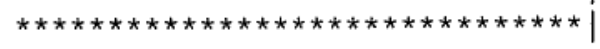 & $|* * * * * * * * \quad * * * * * * * * * * * * * * * * * * * \quad *|$ & | * \\
\hline Ethmostigmus rubripes & 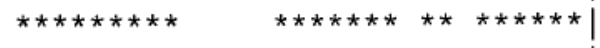 & 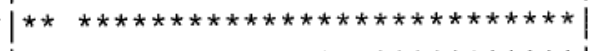 & ** \\
\hline Scolopendra laeta & $* * * * * * * * * * * * * * * * * * * * \quad * \quad$ & 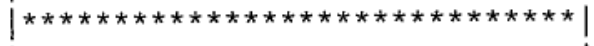 & \\
\hline Allothereua sp. & 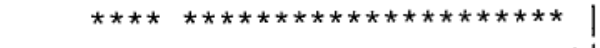 & $|* * * * * * * * * \quad * * \quad * * * * \quad *|$ & * \\
\hline Geophilida spp. & $* \quad * * * * * * * * * * \quad * \mid$ & | $* \quad * * * * * * *$ & \\
\hline Arthrorhabdus sp. & * & 1 & | \\
\hline Ethmostigmus parkeri & * & । & | \\
\hline Arthrorhabdus mjobergi & * & | & | \\
\hline
\end{tabular}

1983d). The present study recorded it from Gascoyne Junction, Kennedy Ranges and Mardathuna (Table 3), all inland localities in the northern portion of the study area. Ethmostigmus parkeri was only taken once at MR1; elsewhere it has only been found on the western edge of the Great Sandy Desert (Koch, 1983d), and the Mardathuna record is a significant range extension.

Scolopendra laeta was previously recorded from several sites in the study area by Kraepelin (1908) and Koch (1982) (Table 1), and we recorded it from all survey areas, with the exception of Gascoyne Junction. It is a widespread species found over much of mainland Australia (Koch, 1982). Scolopendra morsitans is a cosmopolitan species which is found over much of the drier portions of Australia. It has been previously recorded from several sites in the Carnarvon basin (Kraepelin, 1908; Koch, 1983a); Table 1), and we recorded it from all study sites except EL1, EL2 and PE1. It seems to be ubiquitous throughout the Carnarvon basin.

\section{Scutigerida}

A single, unidentified species of Allothereua was collected during the survey. It was found in all survey areas, with the exception of Nerren Nerren, at 42 of the 63 quadrats sampled.

\section{Assemblage Composition}

The composition of centipede communities were found to be correlated most strongly with rainfall and soil texture. The three-groups of sites defined from the classification showed significant differences in the wettest quarter precipitation $(\mathrm{P}<0.0001$, with Kruskal-Wallis $=30.0)$ (Figure 2a) and with soil potassium $(\mathrm{P}<0.01$, with KruskalWallis $=19.9$ ) (Figure $2 b$ ) and a range of other correlates of soil texture. Group 1 consists of sites which receive less rainfall and have higher potassium levels, whereas group 2 consists of sites which receive higher rainfall and have lower potassium levels. Group 3 comprised very different sites: a sand dune (MD1) and a saline claypan (PE1). Their separation as a distinct group may be an artefact of their low species richness (Table 4). However, PwetQ and $\mathrm{K}\left(\mathrm{HCO}_{3}\right)$ are strongly intercorrelated in the study area.

\section{Diplopoda}

\section{Polydesmida}

Only a single polydesmidan genus, Antichiropus, was represented amongst the material collected during the survey, which is consistent with the results presented by Attems (1911) and by specimens of millipedes held in the collections of the Western Australian Museum. Antichiropus is abundant in south-western Australia where several described and numerous undescribed species are known to occur (Attems, 1911) Harvey, unpublished data), and in South Australia, where A. mammillifer Jeekel is known from Poochera (Jeekel, 1982). The most northerly records are of a troglobitic species, A. humphreysi Shear, recently described from Cape Range (Shear, 1992). The only 
(a) Temperature in the wettest quarter ( $\mathrm{T}$ wetQ), Kruskal-Wallis $=19.3$, df $3, \mathrm{P}<0.0002$.

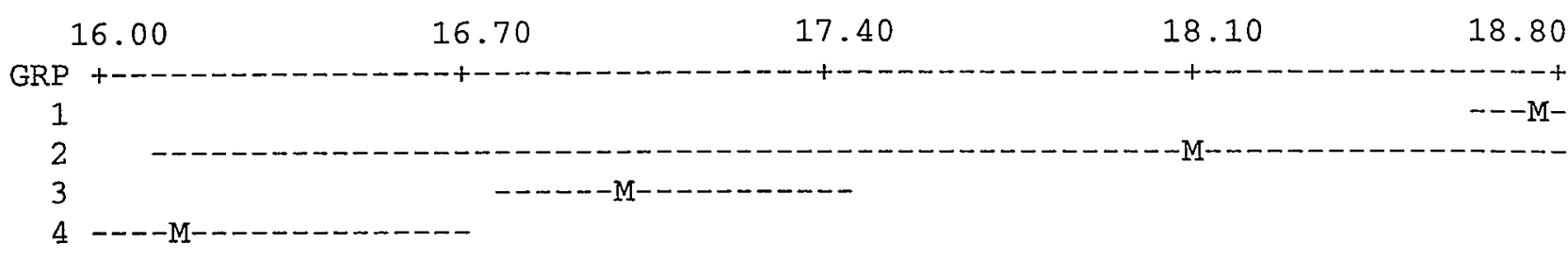

(b) Temperature in the warmest quarter ( $T_{-}$WarQ), Kruskal-Wallis $=20.7$, df 3, $\mathrm{P}<0.0001$.

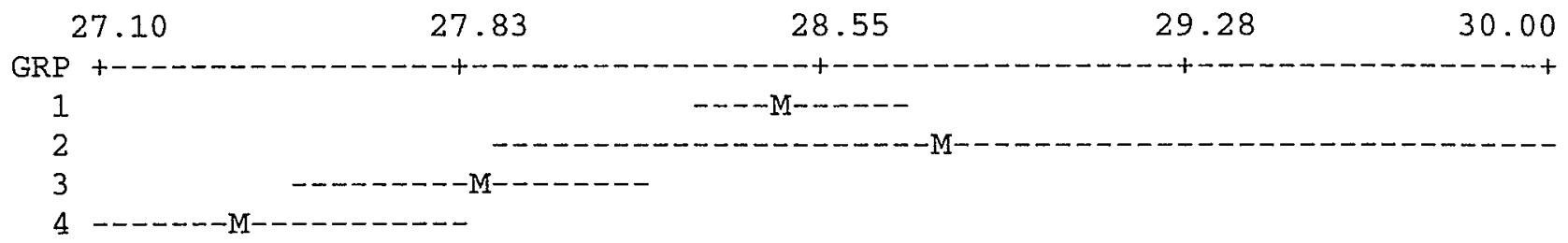

(c) Temperature in the coldest quarter (T cldQ), Kruskal-Wallis $=18.8$, df 3, $\mathrm{P}<0.0003$.

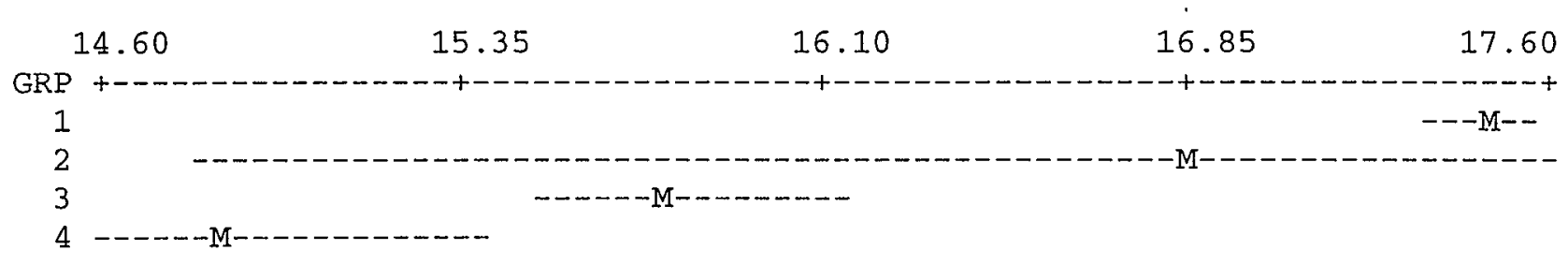

(d) Precipitation in the wettest quarter (P_wetQ), Kruskal-Wallis $=20.8$, df 3, P<0.0001.

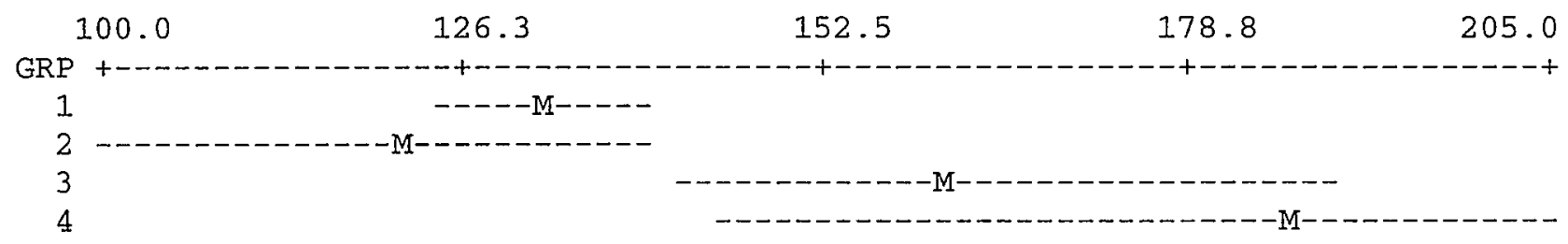

(e) Soil carbon (C), Kruskal-Wallis $=15.9$, df 3, $\mathrm{P}<0.0012$.

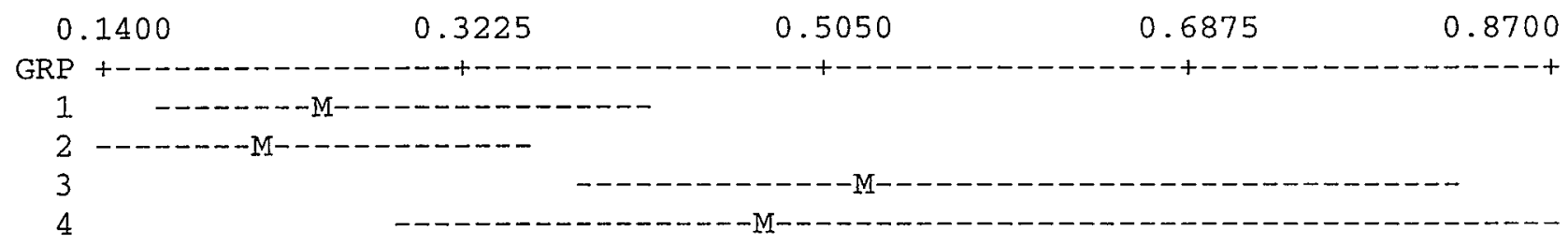

Figure 3 Relationships between UPGMA quadrat groups and selected environmental variables ( $M=$ mean; GRP = quadrat groups delineated in Table 5).

species previously known from the survey region is Antichiropus monocanthus Attems, recorded from Dirk Hartog Island and Tamala by Attems (1911) (Table 1). This species was not recollected during the survey, although seven other species, all undescribed, were taken.

Four species were found to be restricted to individual survey areas: Antichiropus sp. 1 to the five Zuytdorp quadrats (ZU1-5); $A$. sp. 2 to two Nanga quadrats (NA1, NA.5); $A$. sp. 3 to a single
Edel Land site (EL1); and A. sp. 4 to PE4 on Peron Peninsula. Antichiropus sp. 5 was taken from both Nanga (NA3, NA5) and Zutydorp (ZU3). Antichiropus sp. 6 and 7 are probable sister-species, sharing significant similarities in the morphology of the male gonopods. Antichiropus sp. 6 was found only at PE5, whilst $A$.sp. 7 was found at Edel Land (EL2), Nerren Nerren (NE1, NE2) and Zuytdorp (ZU1, ZU3, ZU4, ZU5), all in the southern portion of the survey area. 
Table 5 Millipede data matrix, reordered into groups by classifying species according to their co-occurrences, and quadrats according to similarities in their species composition.

\begin{tabular}{|c|c|c|c|c|c|c|c|}
\hline \multicolumn{8}{|c|}{ Quadrats } \\
\hline Groups: & 1 & & 2 & & 3 & & 4 \\
\hline & B B C B C & 1 & B C CMMN BW & 1 & E P PNNN & | & ENNZZZZZ \\
\hline & OOUOU & 1 & OUURREOO & i & $\mathrm{LEEAA}$ & i & L E EUUUUU \\
\hline & 13446 & i & 22535353 & I & 145135 & 1 & 21213524 \\
\hline & & 1 & & $i$ & & $i$ & \\
\hline Antichiropus sp. 1 & & 1 & & 1 & & 1 & $* * * * *$ \\
\hline Antichiropus sp. 7 & & i & & I & & । & $* * * * * * \quad *$ \\
\hline Siphonotidae sp. 1 & & $i$ & $* * * * * * *$ & 1 & & i & $* * * *$ \\
\hline Antichiropus sp. 5 & & i & & i & $* *$ & i & $*$ \\
\hline Spirostreptida sp. 1 & & $i$ & & $i$ & $* *$ & i & $* * * *$ \\
\hline Antichiropus sp. 2 & & । & & 1 & $* *$ & I & \\
\hline Antichiropus sp. 3 & & 1 & & 1 & $*$ & I & \\
\hline Antichiropus sp. 4 & & i & & i & $*$ & 1 & \\
\hline Antichiropus sp. 6 & & 1 & & 1 & * & 1 & \\
\hline Polyxenidae sp. 1 & $* * * * *$ & i & & 1 & & 1 & \\
\hline Synxenidae sp. 1 & $* *$ & i & $* *$ & I & & i & \\
\hline
\end{tabular}

The restricted distributions of each of the species suggests that $A$. monocanthus may not be found at both Dirk Hartog Island and Tamala as suggested by Attems (1911). Attems did not provide details of the sexes of the material which he examined, and it is possible that one or both of the localities is represented by females or juveniles of a second species. The morphology of the male gonopod is the only morphological feature which separates each species, whereas females and juveniles are indistinguishable from each other. Reexamination of Attems specimens is needed to establish whether A. monocanthus is truly present at both sites.

\section{Polyxenida}

Two species of Polyxenida were recorded during the survey: one was a member of the Polyxenidae and the other a member of the Synxenidae,. The former was taken at Boolathana (BO1, BO3, BO4) and Cape Cuvier (CU4, CU6), while the latter was taken from Boolathana (BO4, BO5), Cape Cuvier (CU6) and Woodleigh (WO3).

\section{Polyzoniida}

A single species of polyzoniidan belonging to the family Siphonotidae was found in several survey areas (Boolathana, Cape Cuvier, Mardathuna, Nerren Nerren and Zutydorp) (Table 5). Polyzoniid millipedes are usually found in wetter biotopes within Western Australia, where they may be commonly found in the Karri (Eucalyptus diversicolor) forests of the south-west. The Carnarvon species most certainly represents an undescribed species, but the relationships of this species with other Western Australian polyzoniids is uncertain.

\section{Spirostreptida}

A single species of Spirostreptida was taken at Nanga (NA3, NA5) and Zuytdorp (ZU2-5).

\section{Assemblage Composition}

Millipedes were very patchily distributed across the study area and were found at only 27 of the 63 study sites (Table 5), which is less than half of the quadrats sampled. For the analyses, we ignored those sites that lacked millipedes. Strong patterning was detected with significant correlations between rainfall and temperature, and other related variables such as soil carbon (Figure 3). In general, most millipede communities are restricted to the wetter, cooler sites, which are largely situated in the woodland regions of the southern portion of the survey area, or are situated along the coast.

\section{DISCUSSION}

\section{Chilopoda}

The strong correlations between centipede communities and environmental variables, most strongly with rainfall and soil texture, are consistent with other groups of organisms examined during this study. In general, there is a greater diversity of centipede species in the drier regions of the survey area, with species such as Asanada sp., Arthrorhabdus paucispinus, Ethmostigmus pachysoma and 
Cormocephalus strigosus found on relatively dry, sandy sites (Table 4, Figure 2).

\section{Diplopoda}

As noted above, millipede community composition is strongly correlated with climate attributes and soil carbon, with most species restricted to either the areas subject to temperate rainfall patterns or in areas which receive coastal rainfall (Table 5).

The relatively small distributions of these seven species of Antichiropus are probably not an artefact, although the short activity period of arid-zone millipedes ensures that the sampling has not been complete throughout the area. In other parts of Western Australia, Antichiropus species have show strongly localised patterns of endemism at the species level (Harvey, unpublished data), and it seems that the group has radiated extensively in suitable habitats throughout south-western Australia, aided by low vagility and a dependence upon suitable habitat.

The Antichiropus species were all taken in the lower half of the survey area, with the most northerly record on Peron Peninsula. The bulk of the localities are within the Southwest Botanical Province (Beard, 1976; 1980; 1990), and even the sites at Nerren Nerren, which cross the boundary between the Southwest and the Eremaean Botanical Provinces, seem to be within this region, as $A$. sp. 7 was found during the period May-August 1995 at sites NE1 and NE2, but was not found at NE3-5 (Table 3). The presence of species of Antichiropus north of Beard's boundary at Peron Peninsula (Table 3) and Dirk Hartog Island (Attems, 1911) provide some support for the hypotheses of Diels (1906) and Burbidge (1960) who included these regions in the Southwest Botanical Province. However, until more is known of the composition and relationships of the millipede fauna of regions to the south and north of the study area, little further can be deduced from these minor transgressions.

\section{ACKNOWLEDGEMENTS}

Funding for this project was provided by the Commonwealth through the National Reserves System Co-operative Program of the Australian Nature Conservation Agency (now Environment Australia), together with State funds provided by the Department of Conservation and Land Management and the Western Australian Museum. We wish to thank those people who ably assisted us in the field program, Mike Lyons for Figure 1, Norm McKenzie for assistance with the numerical analyses, and Norm McKenzie and Bob Mesibov for useful comments on the manuscript.

\section{REFERENCES}

Attems, C.G. (1911). Myriopoda exkl. Scolopendridae. In W. Michaelsen and R. Hartmeyer (eds). Die Fauna Siidwest-Australiens. Vol. 3: 147-204. Gustav Fischer, Jena.

Beard, J.S. (1976). Vegetation survey of Western Australia Murchison 1:1000 000 vegetation series. University of Western Australian Press, Perth.

Beard, J.S. (1980). A new phytogeographic map for Western Australia. Western Australian Herbarium Research Notes 3: 37-58.

Beard, J.S. (1990). Plant life of Western Australia. Kangaroo Press, Kenthurst.

Belbin, L. (1993). PATN: pattern analysis package. CSIRO, Canberra.

Burbidge, N.T. (1960). The phytogeography of the Australian region. Australian Journal of Botany 8: 75221.

Diels, L. (1906). Die Pflanzenwelt von West-Australien südlich des Wendekreisses. Vegetation der Erde 7.

Harvey, M.S. and Waldock, J.W. (1991). Ecological survey of Abydos-Woodstock Reserve, Western Australia. Arachnid and myriapod fauna. Records of the Western Australian Museum, Supplement 37: 126-133.

Harvey, M.S. and Yen, A.L. (1989). Worms to wasps: an illustrated guide to Australia's terrestrial invertebrates. Oxford University Press, Melbourne.

Jeekel, C.A.W. (1982). Millipedes from Australia, 1: Antichiropodini from South Australia (Diplopoda, Polydesmida, Paradoxosomatidae). Bulletin Zoologisch Museum, Universiteit van Amsterdam 8: 121-132.

Jones, R.E. (1998). On the species of the genus Tuoba (Chilopoda: Geophilomorpha) in Australia, New Zealand, New Caledonia, Solomon Islands and New Britain. Records of the Western Australian Museum 18: 333-346.

Keighery, G. (2000). Flora and vegetation of the southern Carnarvon Basin, Western Australia. Records of the Western Australian Museum, Supplement No. 61: 77154.

Koch, L.E. (1982). Taxonomy of the centipede genus Scolopendra laeta Haase (Chilopoda: Scolopendridae) in Australia. Zoological Journal of the Linnean Society 76: $125-140$.

Koch, L.E. (1983a). Morphological characters of the Australian scolopendrid centipedes, and the taxonomy and distribution of Scolopendra morsitans $\mathrm{L}$. (Chilopoda: Scolopendridae: Scolopendrinae). Australian Journal of Zoology 31: 79-91.

Koch, L.E. (1983b). Occurrence in Australia of the centipede genus Asanada Meinert (Chilopoda, Scolopendridae, Scolopendrinae). Records of the Western Australian Museum 11: 75-76.

Koch, L.E. (1983c). Revision of the Australian centipedes of the genus Cormocephalus Newport (Chilopoda: Scolopendridae: Scolopendrinae). Australian Journal of Zoology 31: 799-833.

Koch, L.E. (1983d). A taxonomic study of the centipede genus Ethmostigmus Pocock (Chilopoda: Scolopendridae: Otostigminae) in Australia. Australian Journal of Zoology 31: 835-849.

Koch, L.E. (1984). Australian species of the centipede 
genus Arthrorhabdus Pocock (Chilopoda: Scolopendridae: Scolopendrinae). Journal of Natural History 18: 363-368.

Kraepelin, K. (1908). Scolopendridae. In W. Michaelsen and R. Hartmeyer (eds), Die Fauna SïdwestAustraliens, vol. 2: 105-128. Gustav Fischer, Jena.

McKenzie, N.L., Rolfe, J.K., Aplin, K., Cowan, M. and Smith, L.A. (2000). Herpetofauna of the southern Carnarvon Basin, Western Australia. Records of the Western Australian Museum Supplement No. 61: 335360.

Shear, W.A. (1992). A new genus and two new species of millipedes from the Cape Range, Western Australia (Diplopoda, Polydesmida, Paradoxosomatidae). Records of the Western Australian Museum 15: 777-784.
Sneath, P.H.A. and Sokal, R.R. (1973). Numerical taxonomy: the principles and practice of numerical classification. Freeman, San Francisco.

Wyrwoll, K.-H., Courtney, J. and Sandercock, P. (2000). The climatic environment of the Carnarvon Basin, Western Australia. Records of the Western Australian Museum Supplement No 61: 13-27.

Wyrwoll, K.-H., Stoneman, T., Elliott, G. and Sandercock, P. (2000). The geoecological setting of the study area: geology, geomorphology and soils. Records of the Western Australian Museum Supplement No. 61: 2975 .

Manuscript received 28 June 1999; accepted 7 December 1999. 